\title{
Front Matter: Volume 11149
}

, "Front Matter: Volume 11149," Proc. SPIE 11149, Remote Sensing for Agriculture, Ecosystems, and Hydrology XXI, 1114901 (11 December 2019); doi: $10.1117 / 12.2554500$

SPIE. Event: SPIE Remote Sensing, 2019, Strasbourg, France 


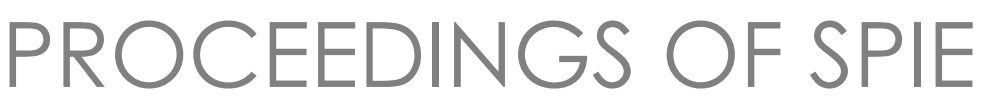

\section{Remote Sensing for Agriculture, Ecosystems, and Hydrology XXI}

Christopher M. U. Neale

Antonino Maltese

Editors

\section{9-11 September 2019}

Strasbourg, France

Sponsored by

SPIE

Cooperating Organisations

European Optical Society

ISPRS - International Society for Photogrammetry and Remote Sensing

EARSeL-European Association of Remote Sensing Laboratories (Germany)

Published by

SPIE 
The papers in this volume were part of the technical conference cited on the cover and title page. Papers were selected and subject to review by the editors and conference program committee. Some conference presentations may not be available for publication. Additional papers and presentation recordings may be available online in the SPIE Digital Library at SPIEDigitalLibrary.org.

The papers reflect the work and thoughts of the authors and are published herein as submitted. The publisher is not responsible for the validity of the information or for any outcomes resulting from reliance thereon.

Please use the following format to cite material from these proceedings:

Author(s), "Title of Paper," in Remote Sensing for Agriculture, Ecosystems, and Hydrology XXI, edited by Christopher M. U. Neale, Antonino Maltese, Proceedings of SPIE Vol. 11149 (SPIE, Bellingham, WA, 2019) Seven-digit Article CID Number.

ISSN: 0277-786X

ISSN: 1996-756X (electronic)

ISBN: 9781510630017

ISBN: 9781510630024 (electronic)

Published by

SPIE

P.O. Box 10, Bellingham, Washington 98227-0010 USA

Telephone +1 3606763290 (Pacific Time) · Fax +1 3606471445

SPIE.org

Copyright (c) 2019, Society of Photo-Optical Instrumentation Engineers.

Copying of material in this book for internal or personal use, or for the internal or personal use of specific clients, beyond the fair use provisions granted by the U.S. Copyright Law is authorized by SPIE subject to payment of copying fees. The Transactional Reporting Service base fee for this volume is $\$ 21.00$ per article (or portion thereof), which should be paid directly to the Copyright Clearance Center (CCC), 222 Rosewood Drive, Danvers, MA 01923. Payment may also be made electronically through CCC Online at copyright.com. Other copying for republication, resale, advertising or promotion, or any form of systematic or multiple reproduction of any material in this book is prohibited except with permission in writing from the publisher. The CCC fee code is 0277$786 \mathrm{X} / 19 / \$ 21.00$.

Printed in the United States of America by Curran Associates, Inc., under license from SPIE.

Publication of record for individual papers is online in the SPIE Digital Library.

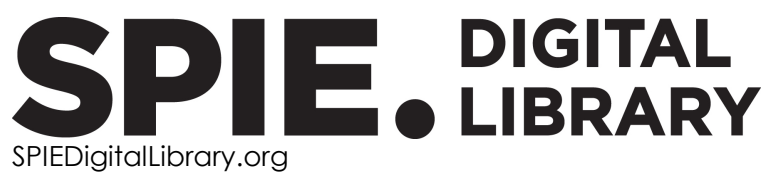

Paper Numbering: Proceedings of SPIE follow an e-First publication model. A unique citation identifier (CID) number is assigned to each article at the time of publication. Utilization of CIDs allows articles to be fully citable as soon as they are published online, and connects the same identifier to all online and print versions of the publication. SPIE uses a seven-digit CID article numbering system structured as follows:

- The first five digits correspond to the SPIE volume number.

- The last two digits indicate publication order within the volume using a Base 36 numbering system employing both numerals and letters. These two-number sets start with $00,01,02,03,04$, 05, 06, 07, 08, 09, 0A, OB ... 0Z, followed by 10-1Z, 20-2Z, etc. The CID Number appears on each page of the manuscript. 


\title{
Contents
}

\author{
ix Authors \\ xi Conference Committee \\ xiii Introduction
}

SESSION 1 SENTINEL-1 AND SENTINEL-3

1114902 Grassland monitoring based on Sentinel-1 [11149-1]

1114903 Evaluation of Sentinel-1 and -2 time series to derive crop phenology and biomass of wheat and rapeseed: northern France and Brittany case studies [1 11 149-2]

1114904 Temporal analysis of Sentinel-1 coherence images [11149-3]

1114905 Spatiotemporal surface water mapping using Sentinel-1 data for regional drought assessment [11149-5]

SESSION 2 SENTINEL-2

1114906 Use of chlorophyll index-green and the red-edge chlorophyll index to derive an algorithm for estimating gross primary production capacity [1 $11149-6]$

1114907 Automated monitoring of small grains in the Middle East and North Africa for food security early warning [1 $11149-7]$

1114908 Comparison of ecosystem functional type patterns at different spatial resolutions in relation with FLUXNET data [1 $11149-8]$

1114909 Sample period dependent classification approach for the cartography of crops in the Haouz plain, Morocco [1 11 149-9]

SESSION 3 UAV, HYPERSPECTRAL, AND HIGH SPATIAL RESOLUTION

$11149 \mathrm{OB} \quad$ Classification of oil palm diseases via spectral unmixing and convolutional neural networks [11149-11]

11149 OD Investigating impacts of calibration methodology and irradiance variations on lightweight drone-based sensor derived surface reflectance products (Best Student Paper Award)

[11149-13] 
$11149 \mathrm{OE} \quad$ Soil fertility status assessment using hyperspectral remote sensing [1 $1149-14]$

SESSION 4 SENTINEL-1 \& -2 PRECISION FARMING

$11149 \mathrm{OF} \quad$ A comparison of retrieval approaches for estimating the seasonal dynamics of rice leaf area index from simulated Sentinel-2 data [ $111149-18]$

SESSION 5 PRECISION FARMING I

$11149 \mathrm{OH} \quad$ Determining crop phenology for different varieties of barley and wheat on intensive plots using proximal remote sensing [11149-19]

$1114901 \quad$ Modelling the ground-LAI to satellite-NDVI (Sentinel-2) relationship considering variability sources due to crop type (Triticum durum L., Zea mays L., and Medicago sativa L.) and farm management [1 $1149-20]$

11149 OK Retrieval and scale effect analysis of LAI over typical farmland from UAV-based hyperspectral data [11149-22]

SESSION $6 \quad$ PRECISION FARMING II

11149 OL Particle swarm optimization for assimilation of remote sensing data in dynamic crop models [11149-23]

11149 OM Wheat ear temperature estimation using a thermal radiometric camera [11149-24]

$11149 \mathrm{ON} \quad$ The influence of shallow groundwater on the actual transpiration flux of irrigated fields using satellite observations [1 11 149-25]

1114900 Porosity effects on red to far-red ratios of light transmitted in natural sands: implications for photoblastic seed germination [1 11 149-26]

\section{SESSION 7 MACHINE LEARNING, DEEP LEARNING, AND CLASSIFICATION}

11149 OP Multi-temporal crop classification with machine learning techniques [11149-28]

$111490 Q \quad$ Texture-based analysis of hydrographical basins with multispectral imagery [11149-29]

11149 OS Farming systems monitoring using machine learning and trend analysis methods based on fitted NDVI time series data in a semi-arid region of Morocco [11149-31]

11149 OT Application of remote sensing and GIS in wetland monitoring and management using Landsat images [1 $11149-32]$

iv 
11149 OU Fire-severity classification across temperate Australian forests: random forests versus spectral index thresholding [1 $11149-34]$

11149 OX A new Copernicus high resolution layer at pan-European scale: small woody features [11 1 149-37]

SESSION 9 HYDROLOGY I

$11149 \mathrm{OZ}$ Investigating the performance of bias correction algorithms on satellite-based precipitation estimates [1 11 149-39]

$1114910 \quad$ Comparison of two datasets from two different satellite sensors at @490 nm in the same spacetemporal window over the Gulf of California area [1 11 149-40]

1114911 Towards using vegetation greening and browning patterns obtained from time series of remote sensing observations for irrigation water management [1 11 149-41]

\section{SESSION 10 HYDROLOGY II}

$1114912 \quad$ Karst investigation program guided by synthetic aperture radar [11149-42]

1114913 Investigating added value of improved DEM, river geometry, and model parameter definitions on flood inundation mapping [1 11 149-43]

$1114914 \quad$ Variations of simulated water use efficiency over 2000-2016 and its driving forces in Northeast China [1 $11149-44]$

$1114915 \quad$ Remote sensing to assess surface water quantity scenarios using normalized difference water index in the lesser Himalayan region [1 11 149-45]

1114916 Assessment of spatial variation of soil moisture during maize growth cycle using SAR observations [ $111149-46]$

\section{SESSION 11 AGRICULTURE AND ECOSYSTEMS}

1114918 Mixed model estimation of rice yield based on NDVI and GNDVI using a satellite image [1 11 149-48]

1114919 Carbon sequestering using remote sensing [11149-49]

11149 1B Analysis of land surface temperature on pastureland areas with different management using Landsat 8 data [1 $1149-51$ ] 
11149 1C Early detection of pink bollworm Pectinophora gossypiella (Saunders) using remote sensing technologies [1 $1149-53]$

\section{POSTER SESSION}

11149 1G Precision arboriculture: a new approach to tree risk management based on geomatics tools [11149-16]

$111491 \mathrm{H} \quad$ Remotely sensed data to support insurance strategies in agriculture [11149-17]

1114911 Assessing the spatiotemporal dynamic of NPP in desert steppe and its response to climate change from 2003 to 2017: a case study in Siziwang banner [1 11 149-52]

$111491 \mathrm{~J}$ Spectral texture classification of high-resolution satellite images for the state forest inventory in Russia [1 1149-56]

$111491 \mathrm{~L} \quad$ Comparison between NDVI and CWSI for waxy corn growth monitoring in field soil conditions [11149-58]

$111491 \mathrm{M}$ Prospects of protective sprays with the use of unmanned aerial vehicles of helicopter type [11149-59]

11149 IQ Identification of plant species of interest for beekeeping in a volcanic landscape [1 $1149-63]$

11149 IT Application of remote sensing for detecting plant disease using color and morphological features [1 11 149-66]

$111491 \mathrm{U}$ Crop identification using superpixels and supervised classification of multispectral CBERS-4 wide-field imagery [1 11 149-67]

11149 IW Agroecosystem zone mapping as a baseline for land suitability evaluation based on remote sensing image processing and geographic information systems in Temanggung regency, Central Java province [1 $11149-69]$

$111491 \mathrm{X} \quad$ Landscape changes at Chernobyl [11149-70]

$111491 Y$ The use of Sentinel-1 and -2 data for monitoring maize production in Rwanda [11149-72]

1114923 Combining remote sensing data and ecosystem modeling to map rooting depth [1 $1149-78$ ]

1114926 Satellite remote sensing detection of forest vegetation land cover changes and their potential drivers [1 $1149-82]$

$1114927 \quad$ Application of remote sensing data for monitoring of forest vegetation on the territory of nature park "Blue Stones," Bulgaria [1 $1149-83]$

1114928 Using optical and radar images to study the thermal pollution from the waste disposal site around Vidin area [1 $1149-84]$ 
1114929 Application of spectral indices and spectral transformation methods for assessment of winter wheat state and functioning [1 11 149-85]

11149 2A Climate change influence on Vegetation Indices (VIs) dynamics upon application of interim ecological monitoring (IEM) based on remote sensing data [1 $1149-86]$ 
Proc. of SPIE Vol. 11149 1114901-8

Downloaded From: https://www.spiedigitallibrary.org/conference-proceedings-of-spie on 26 Apr 2023 Terms of Use: https://www.spiedigitallibrary.org/terms-of-use 


\title{
Conference Committee
}

\author{
Symposium Chairs \\ Christopher M. U. Neale, University of Nebraska Lincoln (United States) \\ Karsten Schulz, Fraunhofer-Institut für Optronik, Systemtechnik und \\ Bildauswertung (Germany) \\ Conference Chairs \\ Christopher M. U. Neale, University of Nebraska Lincoln (United States) \\ Antonino Maltese, Universitá degli Studi di Palermo (Italy)
}


Proc. of SPIE Vol. 11149 1114901-10

Downloaded From: https://www.spiedigitallibrary.org/conference-proceedings-of-spie on 26 Apr 2023 Terms of Use: https://www.spiedigitallibrary.org/terms-of-use 


\section{Authors}

Numbers in the index correspond to the last two digits of the seven-digit citation identifier (CID) article numbering system used in Proceedings of SPIE. The first five digits reflect the volume number. Base 36 numbering is employed for the last two digits and indicates the order of articles within the volume. Numbers start with 00, 01, 02, 03, 04, 05, 06, 07, 08, 09, 0A, 0B...0Z, followed by 10-12, 20-2Z, etc.

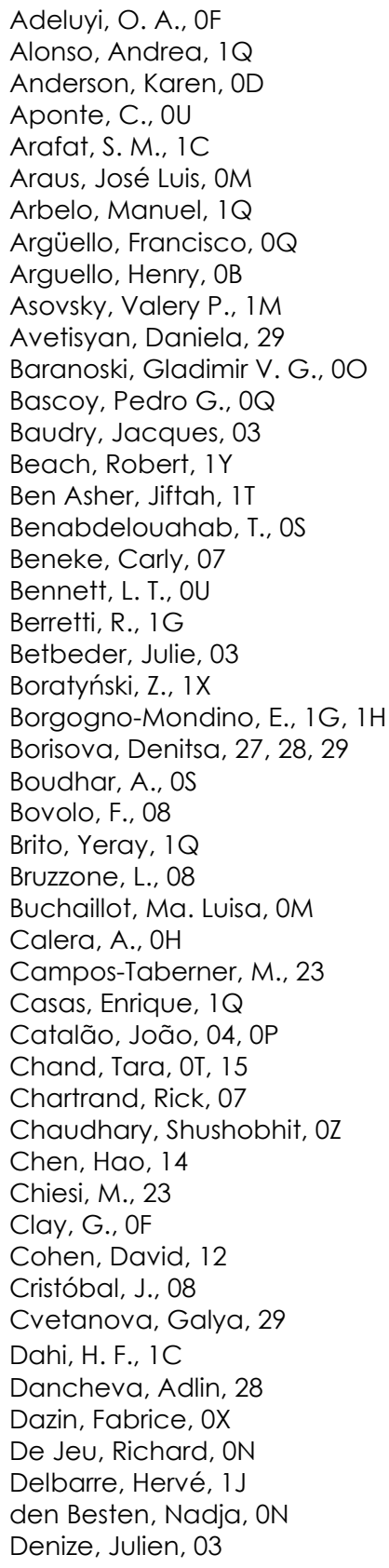

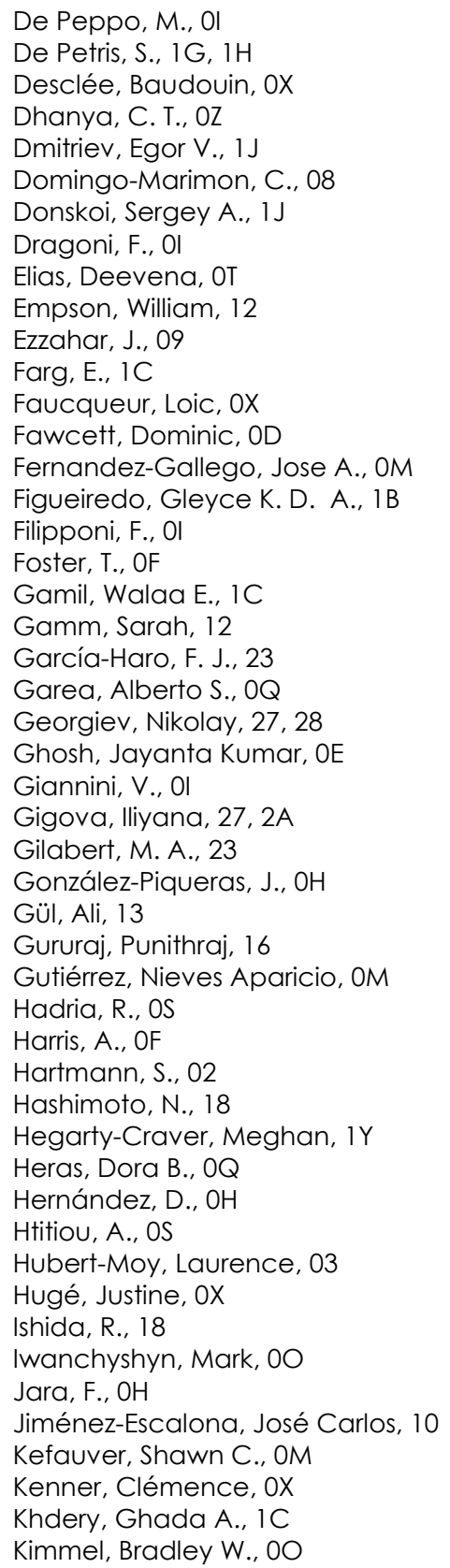


Kontgis, Caitlin, 07

Kopeika, Natan S., IT

Kozoderov, Vladimir $V_{\text {., }} 1 \mathrm{~J}$

Kuzmenko, Alla S., 1M

Lahrouni, A., 09

Lamparelli, Rubens A. C., 1B

Lapidus, Daniel, $1 Y$

Lebrini, Y., OS

Lee, Dong-Ho, $1 \mathrm{~L}$

Leroux, Vincent, 03

$\mathrm{Li}$, Chuanrong, OK, 1 I

Lionbovi, H., OS

López, H., $\mathrm{OH}$

López-Urrea, R., $\mathrm{OH}$

Ma, Lingling, OK

Mantino, A., 0

Marchetti, Francesca, 1Q

Martínez, B., 23

Masci, Olimpia, 04

Maselli, F., 23

Masse, Antoine, OX

Melnik, Petr G., $1 \mathrm{~J}$

Mercier, Audrey, 03

Mira, Nuno Cirne, 04, OP

Mohite, Jayantrao, 05, 11

Morin, Nathalie, OX

Moumni, A., 09

Muramatsu, Kanako, 06

Najar, Mohamed, 13

Nedkov, Roumen, 28, 29, 2A

Nguyen Xuan, A., 01

Nico, Giovanni, 04, OP

Nieto-Taladriz, María Teresa, OM

Oliveira, Julianne C., 1B

O'Neil, Margaret, $1 Y$

Oppelt, Natascha, OL

Ordóñez, Álvaro, OQ

Ottlé, C., 08

Pandit, Ankur, 11

Panidi, Evgeny, 04

Pappula, Srinivasu, 05, 11

Park, Jong-Hwa, 1L

Patel, Ajay Kumar, OE

Pesquer, L., 08

Peylin, P., 08

Pinto, Jhon E., OB

Piso, Gloria, $1 Q$

Polly, Jason, IY

Poom-Medina, José Luis, 10

Radeva, Kameliya, 2A

Ragaglini, G., Ol

Ramírez, Juan M., OB

Redl, S., 02

Remy, Pierre-Yves, OX

Reshef, Yaniv, $1 \mathrm{~T}$

Rich, Dylan, 07

Rineer, James, $1 Y$

Rocha Rodrigues, Eduardo, $1 \mathrm{U}$

Roger, Jean-Luc, 03

Rotko, Daniel, 19
S, Sigit Heru Murti B, IW

Sánchez, J. M., OH

Sánchez-Ruiz, S., 23

Sannier, Christophe, OX

Santos, P. P., IX

Santos, Roberto B., 1B

Sarvia, F., 1G, 1H

Savastru, Dan M., 26

Savastru, Roxana S., 26

Sawant, Suryakant, 05, 11

Schellekens, Jaap, ON

Sebbar, B., 09

Shetty, Amba, 16

Siegmund, R., 02

Sillero, N., 1X

Simonneaux, V., 09

Sokolov, Anton A., $1 \mathrm{~J}$

Spasova, Temenuzhka, 28

Spicher, Fabien, 03

Stoyanov, Andrey, 27

Stupar, Danijela, 19

Surapaneni, Priyanka, 11

Tanase, M. A., OU

Tang, Lingli, OK, 11

Taramelli, A., Ol

Taravat, Alireza, OL

Temple, Dorota S., IY

Teodoro, A. C., $1 \mathrm{X}$

Tornato, A., 0 I

Tran, N. B., OU

Umesh, Pruthviraj, 16

Valentini, E., Ol

Van der Zaag, Pieter, ON

Varsa, Petri, 00

Velizarova, Emiliya, 2A

Villa-Martinez, Hector Antonio, 10

Villodre, J., $\mathrm{OH}$

Volpi, I., Ol

Wagner, M., 02

Wagner, Matthias P., OL

Worsham, Baron, 12

Yadav, Rahul, 15

Yamamoto, T., 18

Yarborough, Sean, 12

Yawata, K., 18

Yones, M. S., $1 \mathrm{C}$

Yoshikawa, H., 18

Zhang, Wanchang, 14

Zhu, Xiaohua, OK, 11

Zilberman, Arkadi, $1 T$

Zoran, Maria A., 26

Zortea, Maciel, $1 \mathrm{U}$ 


\section{Introduction}

This proceedings volume contains papers presented during the Remote Sensing for Agriculture, Ecosystems, and Hydrology XXI conference. The conference was part of the SPIE Remote Sensing symposium held 9-12 September 2019 at the Palais de la Musique et des Congrès in Strasbourg, France. Approximately 40 oral and 20 poster papers were presented during this year's conference, covering a broad range of topics in the field of remote sensing applications for environmental science.

The program was organized into 11 sessions according to major themes, namely, Sentinel-1 and Sentinel-3; Sentinel-2; UAV, Hyperspectral, and High Spatial Resolution; Sentinel-1 and Sentinel-2 Precision Farming; Precision Farming I; Precision Farming II; Machine Learning, Deep Learning, and Classification; Forest; Hydrology I; Hydrology II; and Agriculture and Ecosystems.

The conference Best Student Paper Award was given to the paper, "Investigating impacts of calibration methodology and irradiance variations on lightweight drone-based sensor derived surface reflectance products," by Dominic Fawcett and Karen Ander from the Environment and Sustainability Institute at the University of Exeter (United Kingdom).

The poster presentations also had good representation from the abovementioned session themes. The presentations described both fundamental and applications-based research activities including modelling, laboratory and field experiments, and operational applications.

Our appreciation and gratitude go to the presenters for their efforts, and to the participants for their insightful questions and discussions. Special thanks are also due to the host city for the excellent venue, and to the SPIE staff for their support prior to, during, and after the symposium.

We look forward to an even more successful conference in 2020 in Edinburgh, UK.

Christopher M. U. Neale Antonino Maltese 
Proc. of SPIE Vol. 11149 1114901-14

Downloaded From: https://www.spiedigitallibrary.org/conference-proceedings-of-spie on 26 Apr 2023 Terms of Use: https://www.spiedigitallibrary.org/terms-of-use 